\title{
Soot Reactivity in Conventional Combustion and Oxy-fuel Combustion Environments
}

\author{
Abian, Maria; Jensen, Anker D.; Glarborg, Peter; Alzueta, Maria U.
}

\section{Published in:}

Energy \& Fuels

Link to article, DOI:

10.1021/ef300670q

Publication date:

2012

Document Version

Publisher's PDF, also known as Version of record

Link back to DTU Orbit

Citation (APA):

Abian, M., Jensen, A. D., Glarborg, P., \& Alzueta, M. U. (2012). Soot Reactivity in Conventional Combustion and Oxy-fuel Combustion Environments. Energy \& Fuels, 26(8), 5337-5344. https://doi.org/10.1021/ef300670q

\section{General rights}

Copyright and moral rights for the publications made accessible in the public portal are retained by the authors and/or other copyright owners and it is a condition of accessing publications that users recognise and abide by the legal requirements associated with these rights.

- Users may download and print one copy of any publication from the public portal for the purpose of private study or research.

- You may not further distribute the material or use it for any profit-making activity or commercial gain

- You may freely distribute the URL identifying the publication in the public portal 


\title{
Soot Reactivity in Conventional Combustion and Oxy-fuel Combustion Environments
}

\author{
María Abián, ${ }^{\dagger, \dagger}$ Anker D. Jensen, ${ }^{\dagger}$ Peter Glarborg, $^{\dagger}$ and María U. Alzueta*, ${ }^{\dagger}$ \\ ${ }^{\dagger}$ Department of Chemical and Biochemical Engineering, Technical University of Denmark, Building 229, DK-2800 Lyngby, Denmark \\ ${ }^{\ddagger}$ Aragon Institute of Engineering Research, University of Zaragoza, Río Ebro Campus, C/Mariano Esquillor s/n, 50018 Zaragoza, \\ Spain
}

ABSTRACT: A study of the reactivity of soot produced from ethylene pyrolysis at different temperatures and $\mathrm{CO}_{2}$ atmospheres toward $\mathrm{O}_{2}$ and $\mathrm{CO}_{2}$ has been carried out using a thermogravimetric analyzer. The purpose was to quantify how soot reactivity is affected by the gas environment and temperature history of the carbon, as well as to compare the soot reactivity toward $\mathrm{O}_{2}$ and $\mathrm{CO}_{2}$. Soot samples were either oxidized in $5 \% \mathrm{O}_{2}$ or gasified in 10,50 , and $90 \% \mathrm{CO}_{2}$ atmospheres, during non-isothermal runs at $10 \mathrm{~K} / \mathrm{min}$. Soot oxidation was observed at temperatures of 400-500 K lower than soot gasification, showing higher reactivity toward oxygen than $\mathrm{CO}_{2}$. Independent of the environment history of the soot samples, the soot samples formed at lower temperatures have higher reactivity toward both $\mathrm{O}_{2}$ and $\mathrm{CO}_{2}$ than the soot samples obtained at higher temperatures. The presence of $\mathrm{CO}_{2}$ during the formation of the soot only affected the soot reactivity at the highest formation temperature (1475 $\mathrm{K}$ ) and $\mathrm{CO}_{2}$ concentration (78.5\%). Under these conditions, the soot reactivity was observed to increase by a factor of about 2.6 compared to soot formed in $\mathrm{N}_{2}$ at the same temperature. We attribute the increased reactivity to a higher micropore surface area, facilitated by the gasification reaction at a high temperature. The intrinsic kinetics for oxidation and gasification of soot were obtained by applying the volumetric reaction model.

\section{INTRODUCTION}

It is well-known that soot is one of the main pollutants generated in most combustion processes. Studies related to soot are always a challenge, because it is a very complex material that can be formed through various reaction pathways and under a variety of conditions and can present very different structures, among other factors. Within the combustion chamber, soot may undergo different fates; it may become oxidized by the reaction with $\mathrm{O}_{2}, \mathrm{CO}_{2}$, and other oxidizing compounds $^{1-3}$ or be emitted as sub-micrometer particles.

Most studies of soot have been related to conventional combustion atmospheres (i.e., $\mathrm{O}_{2}$ and $\mathrm{N}_{2}$ ). Recently, oxy-fuel combustion has appeared as a promising technology to mitigate the climate change because of the generation of a $\mathrm{CO}_{2}$-rich gas stream suitable for sequestration, with a feasible application in both existing and new plants. ${ }^{4,5}$ For this reason, investigations related to soot formation and destruction in typical oxy-fuel $\mathrm{CO}_{2}$ atmospheres to identify the possible chemical effect of high $\mathrm{CO}_{2}$ levels on soot behavior at combustion temperatures are important. It has been shown that gasification of some carbon materials results in fine structural rearrangements in the carbon, leading to the loss of surface area and volume in fine pores, ${ }^{6,7}$ and thus, the trends in soot properties can vary significantly depending upon whether the soot is formed in atmospheres with different $\mathrm{CO}_{2}$ concentrations or in $\mathrm{N}_{2}$. Borrego and Álvarez ${ }^{8}$ investigated the properties of char when formed in a drop tube reactor at $1573 \mathrm{~K}$ from coal combustion in $\mathrm{O}_{2} / \mathrm{N}_{2}$ or from oxy-combustion in $\mathrm{O}_{2} / \mathrm{CO}_{2}$. Using a thermogravimetric analyzer (TGA) and micropore surface area measured by $\mathrm{CO}_{2}$ adsorption, they observed that the chars were similar in terms of reactivity by combustion with air at $823 \mathrm{~K}$. However, the chars had different surface areas as determined by
$\mathrm{N}_{2}$ adsorption, and the size distribution of pores was shifted to a larger size for the char obtained in $\mathrm{O}_{2} / \mathrm{CO}_{2}$.

In oxy-fuel $\left(\mathrm{O}_{2} / \mathrm{CO}_{2}\right)$ conditions, $\mathrm{CO}_{2}$ as a reactant may influence soot conversion once formed. Most studies found in the literature on carbon reactivity toward $\mathrm{CO}_{2}$ are related to coal char reactivity. ${ }^{9-12}$ All of them observed a $\mathrm{CO}_{2}$ gasification effect on the coal/char conversion when replacing $\mathrm{N}_{2}$ by $\mathrm{CO}_{2}$. However, studies on soot gasification with $\mathrm{CO}_{2}$ are limited.

In this work, we have carried out an experimental study on the reactivity of soot in different gas environments, which allows us to identify quantitatively how soot reactivity is affected by the environment and temperature history of the carbon, as well as to compare the soot reactivity toward $\mathrm{O}_{2}$ and $\mathrm{CO}_{2}$.

\section{EXPERIMENTAL SECTION}

The reactivity of soot samples obtained from different reaction environments toward $\mathrm{O}_{2}$ and $\mathrm{CO}_{2}$ was measured using a Netzsch STA 449 F1 TGA. The soot samples were prepared in a quartz flow reactor from the pyrolysis of $30000 \mathrm{ppm}$ of ethylene at 1275,1375 , and 1475 $\mathrm{K}$, in different $\mathrm{CO}_{2}$ concentration environments (specifically $0,25,50$, and $78.5 \% \mathrm{CO}_{2}$; Table 1), following the methodology described by Ruiz et al. ${ }^{13}$ and Esarte et al. ${ }^{14}$ The total flow rate in these experiments was $1000 \mathrm{~mL} / \mathrm{min}$ [standard temperature and pressure (STP)], resulting in a gas residence time dependent upon the reaction temperature as $t_{\mathrm{r}}(\mathrm{s})=4550 / T(\mathrm{~K})$. The soot produced in each experiment was collected in a quartz fiber thimble (mesh light lower than $1 \mu \mathrm{m}$ ) placed at the outlet of the reactor. The experiments were

Received: April 20, 2012

Revised: July 2, 2012

Published: July 10, 2012 
Table 1. Formation Conditions of the Soot Samples Investigated

\begin{tabular}{cccc} 
soot sample & ethylene $(\mathrm{ppm})$ & $\mathrm{CO}_{2}(\%)$ & temperature $(\mathrm{K})$ \\
sample 1 & & 1275 \\
sample 2 & 0 & 1375 \\
sample 3 & & 1475 \\
sample 4 & 25 & 1275 \\
sample 5 & & 1375 \\
sample 6 & 30000 & & 1475 \\
sample 7 & & 1275 \\
sample 8 & 50 & 1375 \\
sample 9 & & 1475 \\
sample 10 & & 1275 \\
sample 11 & & 1375 \\
sample 12 & 78.5 & 1475 \\
\hline
\end{tabular}

run for the necessary time to collect a significant amount of soot (higher than $1 \mathrm{~g}$ ).

The evaluation of the soot reactivity has been based on the measurement of the change in sample mass as a function of the temperature and time at a constant heating rate of $10 \mathrm{~K} / \mathrm{min}$ up to $1275 \mathrm{~K}$ in $5 \% \mathrm{O}_{2}$ and up to $1675 \mathrm{~K}$ in 10 , 50, and $90 \% \mathrm{CO}_{2}$, with nitrogen as balance. Alumina crucibles filled with the soot samples, as well as blank reference crucibles, were placed in a highly sensitive balance located in the chamber of the apparatus. The mass of the sample and the crucible temperature were recorded continuously as reaction progressed. For each set of experiments, a calibration curve was made to avoid any possible fluctuations caused by the TGA that could influence the experimental measurements.

The initial sample mass and heating rate used in the TGA experiments was chosen to minimize possible mass-transfer limitations in the oxidation step of the experiments that occur by oxygen gas concentration gradients through the crucible down to the particle bed, through the particle bed, and inside the soot particles. ${ }^{15} \mathrm{~A}$ high initial sample mass and high heating rate may lead to a reaction dominated by diffusion limitations, because the deeper layers of sample would be inaccessible for the oxidant. This may be partly solved by reducing the sample mass, but this may, on the other hand, affect the repeatability of the results. ${ }^{16}$

To evaluate the influence of mass-transfer limitations on the combustion experiments, different sample masses of $1,2,3.5,4$, and 6 $\mathrm{mg}$ (Figure 1) were tested for soot sample 12 in Table 1 . When plotting curves of the time derivative of the mass loss of a carbon as a function of the temperature at a constant heating rate, the peak

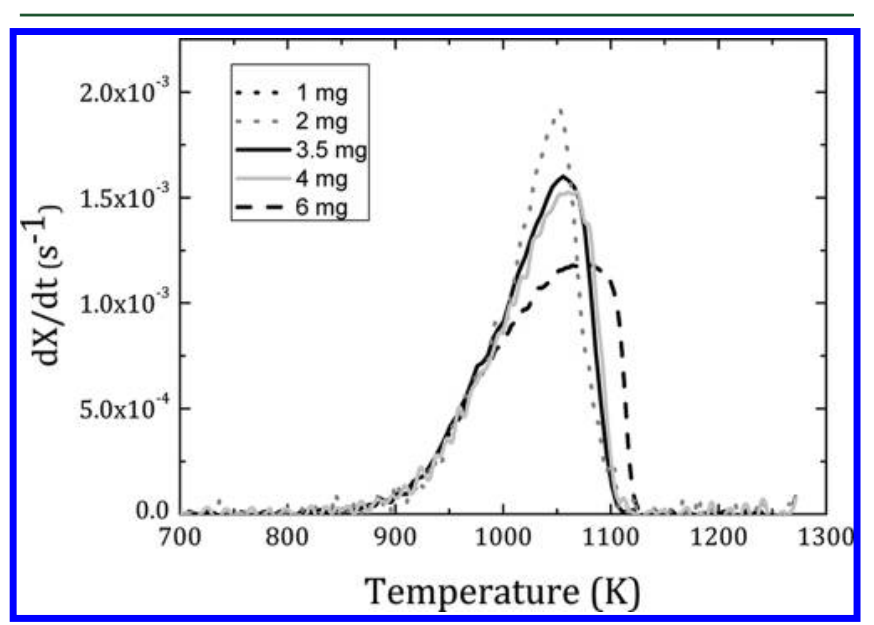

Figure 1. Influence of the soot sample mass for TGA experiments. Oxidation of soot sample 12 (Table 1 ) with $5 \% \mathrm{O}_{2}$ up to $1275 \mathrm{~K}$ at 10 $\mathrm{K} / \mathrm{min}$. Mass loss rate curves from initial soot sample masses of 1 and $2 \mathrm{mg}$ exactly overlap. temperature, PT, where the burning rate is maximum, is a way to express the reactivity of a fuel. ${ }^{17}$ Higher peak temperatures indicate lower reactivity. In such a way, figures in this paper present the soot reactivity as the rate of mass loss, $\mathrm{d} X / \mathrm{d} t\left(\mathrm{~s}^{-1}\right)$, defined by

$$
\frac{\mathrm{d} X}{\mathrm{~d} t}=\frac{1}{m_{\mathrm{o}}} \frac{\mathrm{d} m}{\mathrm{~d} t}
$$

Here, $m_{0}$ is the initial mass of soot, and $m$ is the mass of soot at time $t$. The experimental mass and the mass loss rate curves were smoothed for clarity.

It can be inferred from the results in Figure 1 that the rate of mass loss and peak temperature are quite similar for masses lower than $4 \mathrm{mg}$ and, in particular for initial sample masses of 1 and $2 \mathrm{mg}$, the general profile shape and peak temperature exactly match each other, demonstrating the good repeatability of the soot oxidation in the TGA and the absence of mass-transfer limitations. For higher initial soot masses, i.e., $6 \mathrm{mg}$, the results indicate the presence of diffusion limitations because the mass loss rate decreases and the PT increases in comparison to the results attained with lower masses.

On the basis of these results, usually less than $3.5 \mathrm{mg}$ of soot samples was applied in the oxidation/gasification experiments.

\section{RESULTS AND DISCUSSION}

To establish how the reactivity toward $\mathrm{O}_{2}$ is affected by both the soot formation environment and temperature history of the soot, the soot particles were oxidized in $5 \% \mathrm{O}_{2}$ at a heating rate of $10 \mathrm{~K} \mathrm{~min}^{-1}$ to a maximum temperature of $1275 \mathrm{~K}$. The influence of the temperature history of the soot is considered initially. Figure 2 shows the mass loss rate $d X / d t$ versus $T$ as a function of the soot formation temperature for the soot formed in the $0,25,50$, and $78.5 \% \mathrm{CO}_{2}$ atmosphere. In general, the peak temperature is shifted to higher values as the soot formation temperature is increased. For example, in Figure 2a, the soot formed in a $\mathrm{N}_{2}$ atmosphere at $1275 \mathrm{~K}$ (set 1 in Table 1) has the PT at $927 \mathrm{~K}$, whereas the soot formed in a $\mathrm{N}_{2}$ atmosphere at $1475 \mathrm{~K}$ (set 3 in Table 1 ) has the PT at $1102 \mathrm{~K}$. This behavior is independent of the $\mathrm{CO}_{2}$ concentration in the reaction environment, and thus, a decrease in soot sample reactivity with an increasing soot formation temperature is observed.

It can be seen that some of the soot samples present a double peak in the $\mathrm{d} X / \mathrm{d} t$ versus $T$ curve (DGT peak), particularly samples 8 and 11 in Table 1. Double DGT peaks have also been detected in studies of char reactivity. Russell et al. ${ }^{18}$ concluded that single narrow peaks can be interpreted to represent homogeneous char, single broadened peaks would represent a more heterogeneous mixture and double peaks would correspond to a clear bimodal combination of two constituents with different reactivity, as was also suggested by Zolin et al. ${ }^{15}$ and Zhang et al. ${ }^{19}$

The presence of two peaks in the $\mathrm{d} X / \mathrm{d} t$ versus $T$ curve can indicate the transformation of a reactive phase into a less reactive phase with an increasing soot formation temperature. For $1475 \mathrm{~K}$, the formation of two peaks is less evident; mostly, a single peak is observed and positioned at higher temperatures, indicating that most of the soot is converted into the less reactive phase. This loss in soot reactivity when increasing its formation temperature has also been observed in other studies on soot and char reactivity. ${ }^{7,15,20}$ Thermal annealing has been suggested as one of the main mechanisms involved in char reactivity loss (deactivation) during combustion. It has been reported that the exposure of the fuel to high temperatures in the boiler causes a thermal annealing of the particles, characterized by the loss of surface area, loss of active sites, 


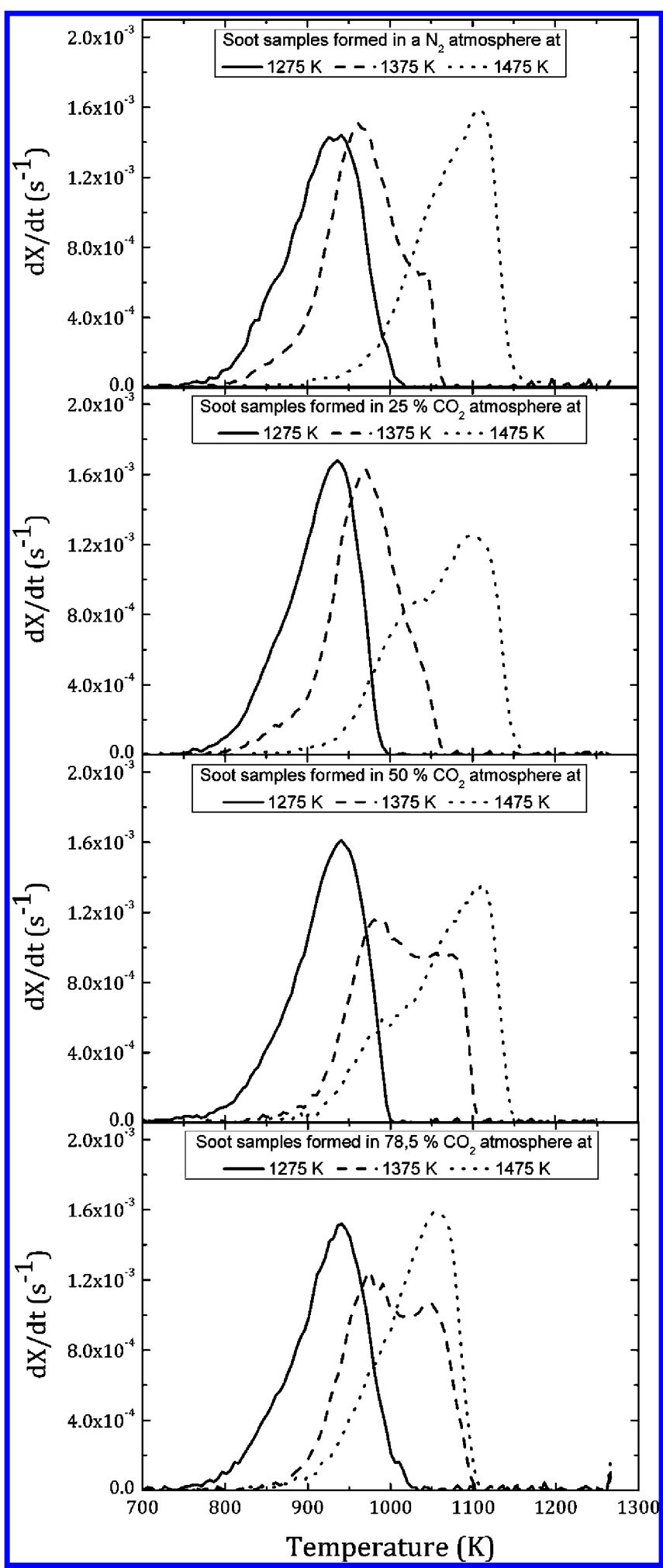

Figure 2. Oxidation profiles of the soot samples prepared in different $\mathrm{CO}_{2}$ environments as a function of the reaction temperature: (a) $0 \%$ $\mathrm{CO}_{2}$ (sets 1-3 in Table 1), (b) 25\% $\mathrm{CO}_{2}$ (sets 4-6 in Table 1), (c) $50 \% \mathrm{CO}_{2}$ (sets $7-9$ in Table 1 ), and (d) $78.5 \% \mathrm{CO}_{2}$ (sets $10-12$ in Table 1). Soot particles were oxidized with $5 \% \mathrm{O}_{2}$ up to $1275 \mathrm{~K}$ at 10 $\mathrm{K} / \mathrm{min}$.

and/or loss of active site reactivity. ${ }^{15}$ Zolin et al. ${ }^{15}$ performed an extensive experimental study of char thermal deactivation based on reactivity experiments of different fuel chars. They observed a clear tendency to develop two phases as the heat treatment temperature (HTT) increased, with the less reactive phase of those coals gradually approaching the reactivity of commercial graphite, hence suggesting a high degree of crystalline order. They explained the gradual formation of two phases in the TGA found for some of the coal chars as follows: At low HTTs, where only one peak was attained, the basic structural units or crystallites, responsible for the graphitization or annealing of the char, are of small size and probably also their chemical composition still resembles the other parts of the char and, thus, does not lead to a clear-cut separate ordered region in the char. At higher HTTs, further volatile release may be accompanied by the removal of the organic units attached to the crystallites and the rest of the char, allowing for the crystallites to increase in size and concentration and to reorganize into more graphite-like alignments. At this point, clear-cut regions of crystalline order may exist, and as a result, the char splits into two fractions with different reactivity.

These findings would be expected to be valid also for soot. Ruiz et al. $^{7}$ have reported that, at elevated soot formation temperatures, a graphitization process occurs that may lead to a less reactive soot. It has also been reported in the literature that the hydrogen content can be directly related to the availability of active sites of the solid and, thus, to its reactivity. ${ }^{21,22}$ In this context, Ruiz et al. ${ }^{7}$ carried out reactivity experiments of the soot formed from acetylene pyrolysis at different temperatures. They noticed through elemental analysis that, in general, higher soot formation temperatures result in higher carbon contents and lower hydrogen contents and related this tendency to the reactivity results because the soot samples formed at lower temperatures were the most reactive. Elemental analyses of representative soot samples (samples 2 and 3 in Table 1) indicate that higher soot formation temperatures result in higher carbon contents and lower hydrogen contents, in agreement with the conclusions cited above. Table 2 shows the results of the elemental analyses of these soot samples, as well as the $\mathrm{C} / \mathrm{H}$ ratio on a molar basis.

Table 2. Elemental Analysis and C/H Ratio (Molar Basis) of Soot Samples Obtained at Different Temperatures in a $\mathbf{N}_{2}$ Atmosphere

\begin{tabular}{cccccc} 
& \multicolumn{4}{c}{$\begin{array}{c}\text { elemental analysis (wt \%) } \\
\text { (dry basis) }\end{array}$} \\
\cline { 2 - 5 } soot samples & $\mathrm{C}$ & $\mathrm{H}$ & $\mathrm{N}$ & $\mathrm{S}$ & $\mathrm{C} / \mathrm{H}$ (molar basis) \\
\cline { 2 - 5 } sample 2 & 97.77 & 1.01 & 0 & 0 & 96.80 \\
sample 3 & 99.71 & 0.37 & 0 & 0 & 269.49 \\
\hline
\end{tabular}

The influence of the $\mathrm{CO}_{2}$ concentration during soot formation is illustrated in Figure 3, which shows the mass loss rate in $\mathrm{d} X / \mathrm{d} t$ versus $T$ as function of the soot formation environment for specific soot formation temperatures. In this case, no clear tendencies can be observed because, dependent upon the soot formation temperature, the $\mathrm{CO}_{2}$ atmosphere present in the formation of the soot samples plays a different role. At $1275 \mathrm{~K}$, the soot formation environment does not significantly affect the soot sample reactivity, and the peak temperatures for the different $\mathrm{CO}_{2}$ soot formation atmospheres are approximately at $935 \mathrm{~K}$. At $1375 \mathrm{~K}$, although in general there are no clear differences in reactivity of the soot formed in the different $\mathrm{CO}_{2}$ atmospheres, for the soot samples formed with 50 and $78.5 \% \mathrm{CO}_{2}$, a second less reactive phase in the soot oxidation begins to appear, indicated by the two peaks in the 


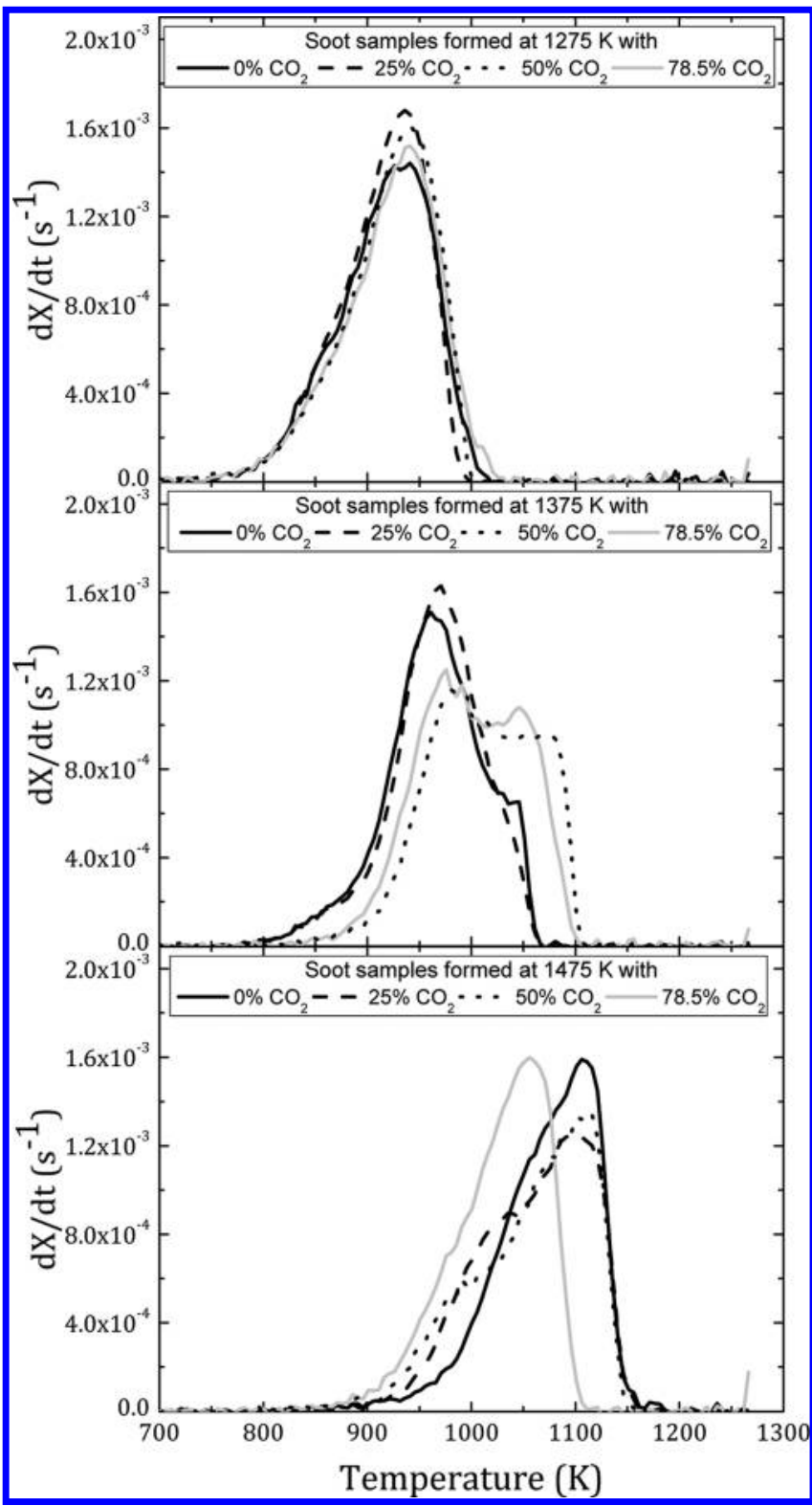

Figure 3. Oxidation profiles of the soot samples prepared at different temperatures as function of the $\mathrm{CO}_{2}$ reaction environment: (a) $1275 \mathrm{~K}$ (sets 1, 4, 7, and 10 in Table 1), (b) $1375 \mathrm{~K}$ (sets 2, 5, 8, and 11 in Table 1), and (c) $1475 \mathrm{~K}$ (sets 3, 6, 9, and 12 in Table 1). Soot particles were oxidized with $5 \% \mathrm{O}_{2}$ up to $1275 \mathrm{~K}$ at $10 \mathrm{~K} / \mathrm{min}$.

$\mathrm{d} X / \mathrm{d} t$ versus $T$ curve. At $1475 \mathrm{~K}$, an appreciable mass loss of the soot samples formed with 25,50 , and $78.5 \% \mathrm{CO}_{2}$ takes places at lower temperatures than the initiation mass loss temperature for the soot formed in the $\mathrm{N}_{2}$ atmosphere. The promoting effect of $\mathrm{CO}_{2}$ increases with the $\mathrm{CO}_{2}$ concentration in the soot formation environment, and the soot sample reactivity, represented by the lower PT is highest for the $78.5 \%$ $\mathrm{CO}_{2}$ concentration $(78.5 \%)$.

The increase in reactivity could imply an effect of $\mathrm{CO}_{2}$ at high temperatures during the formation of the soot sample 12 (Table 1). This is probably due to the generation of micropores with a high surface area because of gasification by $\mathrm{CO}_{2}$. Adsorption isotherms of the soot samples formed at $1475 \mathrm{~K}$ with $\mathrm{N}_{2}$ (soot 3 in Table1) and with $78.5 \% \mathrm{CO}_{2}$ (soot 12 in Table 1) have been determined by both $\mathrm{CO}_{2}$ adsorption at 273 $\mathrm{K}$ and quantified using the Dubinin-Radushkevich method and by nitrogen adsorption at $77 \mathrm{~K}$ in combination with the Brunauer-Emmett-Teller (BET) adsorption isotherm model.

The $\mathrm{CO}_{2}$ surface area measurements confirm that the soot sample formed in the $78.5 \% \mathrm{CO}_{2}$ atmosphere has a higher micropore surface area $\left(117 \mathrm{~m}^{2} / \mathrm{g}\right.$ for soot sample 12 ; Table 1$)$ than the soot sample formed in the $\mathrm{N}_{2}$ atmosphere $\left(20 \mathrm{~m}^{2} / \mathrm{g}\right.$ for soot sample 3; Table 1). In the case of surface areas determined from $\mathrm{N}_{2}$ adsorption isotherms, the soot sample formed in the $78.5 \% \mathrm{CO}_{2}$ atmosphere (sample 12 in Table 1) presents a BET surface area of $9.6 \mathrm{~m}^{2} / \mathrm{g}$, while the BET surface area for the soot sample formed in the $\mathrm{N}_{2}$ atmosphere (sample 3 in Table 1) is $14.4 \mathrm{~m}^{2} / \mathrm{g}$. These area values are very low, and the differences between samples are not considerable.

It has been suggested in the literature that the graphitization process is accelerated by the presence of $\mathrm{O}_{2}$ or $\mathrm{CO}_{2}$ in the gas phase, because oxidizing gases preferentially attack less ordered carbon, removing cross-linkages between graphitic crystallites and accelerating crystallite grow. ${ }^{6}$ In addition, the graphitization process can lead to lower surface area values.' Under the conditions of $78.5 \% \mathrm{CO}_{2}$ and $1475 \mathrm{~K}$, it appears that, even if the presence of $\mathrm{CO}_{2}$ may lead to some additional graphitization, the positive effect of $\mathrm{CO}_{2}$ from generating microporosity is dominating, leading to enhanced reactivity.

To assess the influence of $\mathrm{CO}_{2}$ gasification on soot conversion, soot particles were gasified in 10, 50, and $90 \%$ $\mathrm{CO}_{2}$ at a heating rate of $10 \mathrm{~K} \mathrm{~min}^{-1}$ to a maximum temperature of $1675 \mathrm{~K}$, using sample 12 in Table 1 . On the basis of experience from the oxidation experiments, sample masses of around 2-3 mg were used. Figure 4 shows the results of these

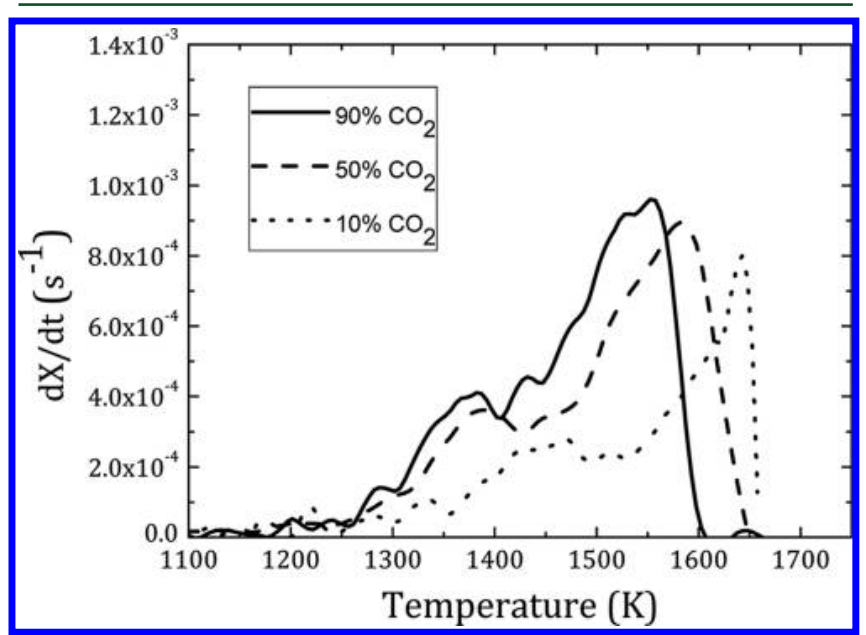

Figure 4. Gasification profiles of soot sample 12 (Table 1) in atmospheres consisting of 10,50 , and $90 \% \mathrm{CO}_{2}$ up to $1675 \mathrm{~K}$ at $10 \mathrm{~K} /$ min.

experiments. It can be observed that, independent of the $\mathrm{CO}_{2}$ concentration, gasification is appreciable at temperatures above $1250 \mathrm{~K}$. In general, this initiation temperature is slightly higher than the one found for coal char gasification in TGA, i.e., around $1030 \mathrm{~K}^{12}$ or $1073 \mathrm{~K}^{9,11} \mathrm{It}$ is also observed, as expected, that the gasification rate increases with the $\mathrm{CO}_{2}$ concentration. The lowest peak temperature of $1525 \mathrm{~K}$ is obtained with $90 \%$ $\mathrm{CO}_{2}$, whereas for the lowest $\mathrm{CO}_{2}$ concentration (10\%), the soot sample is not totally consumed even at the highest temperatures analyzed.

To evaluate the influence of the environment/temperature history of the soot in relation to its reactivity toward $\mathrm{CO}_{2}$, TGA 
gasification experiments have been performed at a heating rate of $10 \mathrm{~K} \mathrm{~min}^{-1}$ up to $1675 \mathrm{~K}$ in $50 \% \mathrm{CO}_{2}$ with soot samples obtained at $1275 \mathrm{~K}$ in $0 \% \mathrm{CO}_{2}$ (sample 1 ) and $78.5 \% \mathrm{CO}_{2}$ (sample 10) and soot samples obtained at $1475 \mathrm{~K}$ in $0 \% \mathrm{CO}_{2}$ (sample 3 ) and $78.5 \% \mathrm{CO}_{2}$ (sample 12 ). The $\mathrm{dX} / \mathrm{d} t$ versus $T$ results for these experiments are presented in Figure 5. It can

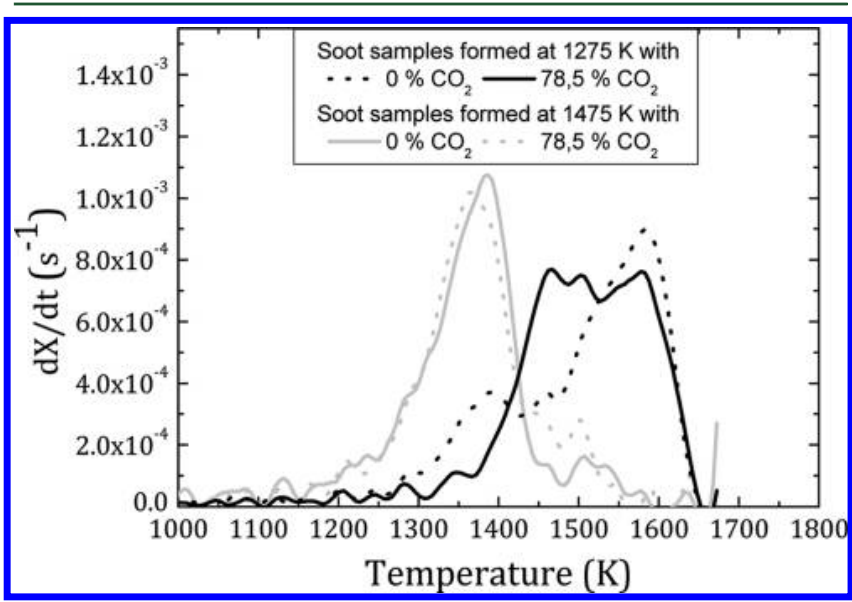

Figure 5. Gasification profiles of selected soot samples prepared at different temperatures and $\mathrm{CO}_{2}$ reaction environments (sets $1,3,10$, and 12 in Table 1). Soot particles were gasified with $50 \% \mathrm{CO}_{2}$ up to $1675 \mathrm{~K}$ at $10 \mathrm{~K} / \mathrm{min}$.

be observed that, independent of the soot formation environment, the soot produced at lower temperatures $(1275 \mathrm{~K})$ reacts at lower temperatures than that produced at higher temperatures $(1475 \mathrm{~K})$. These results are consistent with the observations drawn from Figure 2 for the oxidation experiments. For the soot samples formed at $1275 \mathrm{~K}$, there is no appreciable influence of the reaction environment (0-78.5\% $\mathrm{CO}_{2}$ ), because this temperature is too low for $\mathrm{CO}_{2}$ gasification to take place, and thus, no microporosity is expected. For the soot samples obtained at $1475 \mathrm{~K}$, it can be observed in the $\mathrm{dX}$ / $\mathrm{d} t$ versus $T$ profile that the soot sample formed in the $\mathrm{N}_{2}$ atmosphere (soot 3 in Table 1) presents a single broadened peak, and the soot sample formed in the $78.5 \% \mathrm{CO}_{2}$ atmosphere (soot 12 in Table 1) presents two peaks, with the smaller peak at lower temperatures and the higher second peak at higher temperatures. Although in general the reactivity of these soot samples toward $\mathrm{CO}_{2}$ is not considerably changed, the mass loss of the soot sample formed in the $78.5 \% \mathrm{CO}_{2}$ environment is appreciable at lower temperatures than for the soot sample formed in the $\mathrm{N}_{2}$ atmosphere. It is also remarkable that the larger consumption of these soot samples is initiated at temperatures around their formation temperature (1475 K).

The oxidation and gasification kinetics of soot have been derived from the experimental mass loss data according to a volumetric reaction model $(\mathrm{VRM})^{23}$ given by

$$
\begin{aligned}
& \text { rate }=\frac{-1}{m}\left(\frac{\mathrm{d} m}{\mathrm{~d} t}\right)=\frac{1}{1-X}\left(\frac{\mathrm{d} X}{\mathrm{~d} t}\right)=k_{0} \mathrm{e}^{-E_{\mathrm{a}} / R T} \\
& X=\frac{m_{0}-m}{m_{0}}
\end{aligned}
$$

Here, rate $\left(\mathrm{mg} \mathrm{mg}^{-1} \mathrm{~s}^{-1}\right)$ represents the reaction rate based on the instantaneous mass of soot. $m_{0}$ and $m$ are the initial carbon mass (mg) and the carbon mass at a certain time, $t$, respectively. $X$ is the carbon conversion at any time. $R\left(\mathrm{~kJ} \mathrm{~mol}^{-1} \mathrm{~K}^{-1}\right)$ is the ideal gas constant. $E_{\mathrm{a}}(\mathrm{kJ} / \mathrm{mol})$ is the activation energy. $k_{0}\left(\mathrm{~s}^{-1}\right)$ is the pre-exponential factor. $T(\mathrm{~K})$ is the reaction temperature. When the oxidation/gasification data were fitted to the VRM model, $k_{0}$ and $E_{\mathrm{a}}$ were determined. In the kinetic analysis, we have neglected soot samples with two distinct phases of different reactivity. Samples with a minor second peak however were included, but in this case, the fitting only involved the conversion range of the main peak. Figures 6 and 7 show the

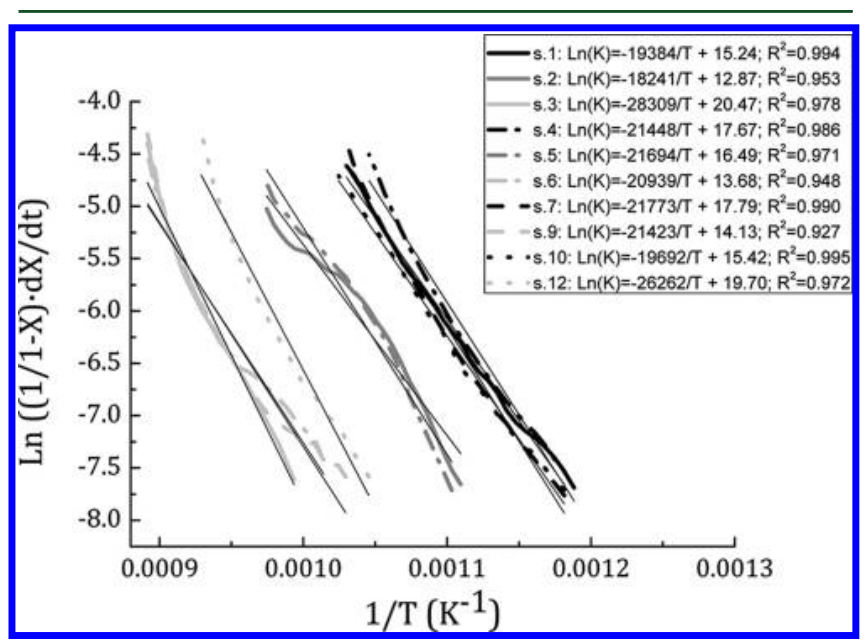

Figure 6. Arrhenius plots of oxidation rate constants with $5 \% \mathrm{O}_{2}$ for soot obtained under different temperature $/ \mathrm{CO}_{2}$ environment conditions (sets $1-12$ in Table 1).

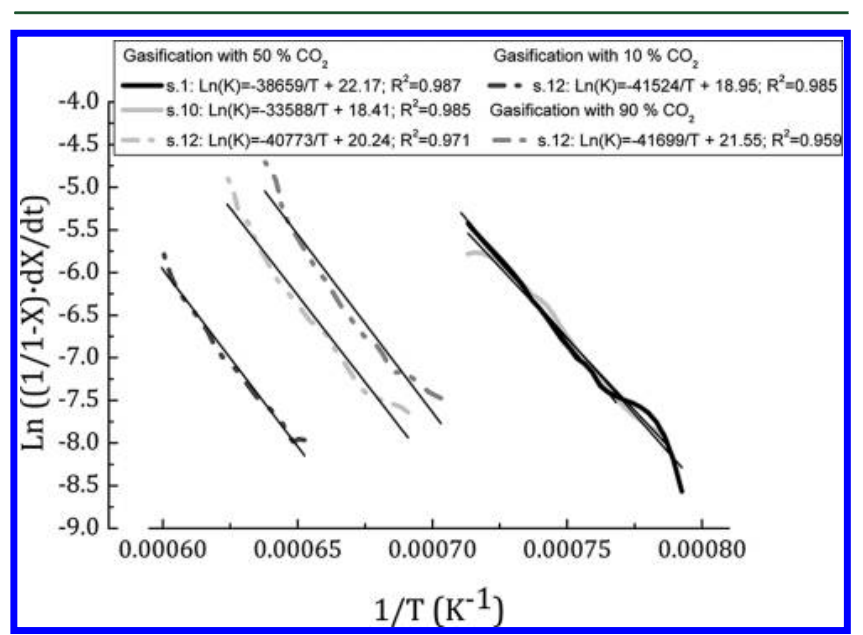

Figure 7. Arrhenius plots of gasification rate constants for soot obtained under different temperature $/ \mathrm{CO}_{2}$ environment conditions: sets 1, 10, and 12 in Table 1 for gasification with $50 \% \mathrm{CO}_{2}$ and set 12 in Table 1 for gasification with 10 and $90 \% \mathrm{CO}_{2}$.

Arrhenius plots for combustion and gasification, respectively, of soot samples obtained from the different temperature/environment conditions, along with the linear regression results for each soot.

Table 3 summarizes the activation energy for the oxidation of soot samples 1-12 and for the gasification of soot samples 1, 10 , and 12. The oxidation of soot samples shows activation energies in the range of $152-235 \mathrm{~kJ} / \mathrm{mol}$, while the corresponding values for gasification are in the range of 279$347 \mathrm{~kJ} / \mathrm{mol}$, with most of the soot samples presenting $E_{\mathrm{a}}$ values in the $300-347 \mathrm{~kJ} / \mathrm{mol}$ range.

In their review on soot oxidation, Stanmore et al. ${ }^{1}$ found that activation energies for soot oxidation cover a range of 102-210 
Table 3. Kinetic Constants of Soot Oxidation with $5 \% \mathrm{O}_{2}$ and Gasification with $50 \% \mathrm{CO}_{2}{ }^{a}$

\begin{tabular}{|c|c|c|c|}
\hline & $E_{\mathrm{a}}(\mathrm{kJ} / \mathrm{mol})$ & common $E_{\mathrm{a}}(\mathrm{kJ} / \mathrm{mol})$ & $k_{0}\left(\mathrm{~s}^{-1}\right)(\mathrm{VRM})$ \\
\hline \multicolumn{4}{|c|}{ Oxidation } \\
\hline sample 1 & 161 & \multirow{10}{*}{182} & $7.61 \times 10^{7}$ \\
\hline sample 2 & 152 & & $2.04 \times 10^{7}$ \\
\hline sample 3 & 235 & & $1.76 \times 10^{6}$ \\
\hline sample 4 & 178 & & $8.49 \times 10^{7}$ \\
\hline sample 5 & 180 & & $1.99 \times 10^{7}$ \\
\hline sample 6 & 174 & & $2.25 \times 10^{6}$ \\
\hline sample 7 & 181 & & $6.77 \times 10^{7}$ \\
\hline sample 9 & 178 & & $2.30 \times 10^{6}$ \\
\hline sample 10 & 164 & & $6.50 \times 10^{7}$ \\
\hline sample 12 & 218 & & $4.83 \times 10^{6}$ \\
\hline \multicolumn{4}{|c|}{ Gasification } \\
\hline sample 1 & 321 & \multirow{3}{*}{326} & $1.18 \times 10^{10}$ \\
\hline sample 10 & 279 & & $1.05 \times 10^{10}$ \\
\hline sample 12 & 339 & & $4.18 \times 10^{8}$ \\
\hline
\end{tabular}

$\mathrm{kJ} / \mathrm{mol}$, with values between 140 and $170 \mathrm{~kJ} / \mathrm{mol}$ appearing frequently. Therefore, the range of activation energies for soot oxidation found in this study is in reasonable agreement with previous research work. To our knowledge, no values of activation energies have been reported in the literature for the soot gasification with $\mathrm{CO}_{2}$.

To compare the relative reactivity of the different soot samples as a function of their temperature/environment history, the activation energy was fixed at a common value in eq 2 for the oxidation and gasification experiments, respectively, while the pre-exponential factor $k_{0}\left(\mathrm{~s}^{-1}\right)$ was obtained as a single parameter in the model. The input to the fitting procedure has been the values of time and soot conversion at a heating rate of $10 \mathrm{~K} \mathrm{~min}^{-1}$ and a mean activation energy $E_{\mathrm{a}}$ of $182 \mathrm{~kJ} / \mathrm{mol}$ for the soot oxidation and $E_{\mathrm{a}}$ of $326 \mathrm{~kJ} / \mathrm{mol}$ for the soot gasification. The best fit corresponded to the value of $k_{0}$ $\left(\mathrm{s}^{-1}\right)$ that minimized the sum of squares of the differences between experimental and calculated conversion values. As an example of the qualitative interpretation of the soot oxidation/ gasification profiles, Figure 8 presents the data corresponding to the experimental and model predictions according to the VRM of soot samples 10 and 12 in Table 1 using a common activation energy for all soot samples of $182 \mathrm{~kJ} / \mathrm{mol}$ when oxidized with $5 \% \mathrm{O}_{2}$ and $326 \mathrm{~kJ} / \mathrm{mol}$ when gasified with $50 \%$ $\mathrm{CO}_{2}$. It can be noticed that the model based on a common activation energy predicts fairly well the experimental results.

The calculated $k_{0}\left(\mathrm{~s}^{-1}\right)$ values are presented in Table 3 and summarized in Figure 9. It can be observed that the reestimated $k_{0}$ values of both the oxidation and gasification experiments decrease as the soot formation temperature increases, independent of the $\mathrm{CO}_{2}$ concentration in the soot formation environment, suggesting that thermal deactivation of the soot takes place as the soot formation temperature increases. However, there are no clear differences in relation to the gas environment of the soot samples.

The onset of reaction with $\mathrm{O}_{2}$ for all soot samples studied is observed at temperatures about $450 \mathrm{~K}$ lower than the corresponding value for $\mathrm{CO}_{2}$, confirming that oxidation is much faster than gasification at these temperatures. For example, in quantitative terms, oxidation of soot sample 10 in

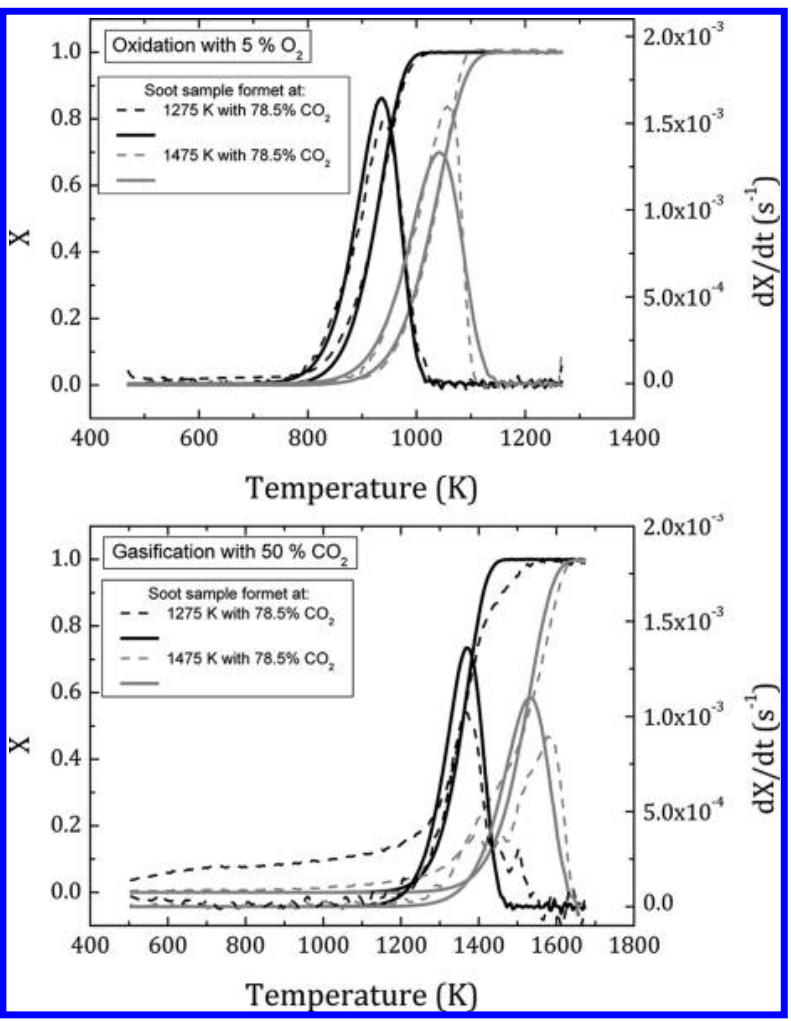

Figure 8. Oxidation (upper panel) and gasification (bottom panel) profiles of soot sample 10 in Table 1 (black lines) and soot sample 12 in Table 1 (gray lines). Experimental data are displayed as dashed thin lines. Model data (VRM) are displayed as continuous thick lines. Soot particles were oxidized with $5 \% \mathrm{O}_{2}$ up to $1275 \mathrm{~K}$ and gasified with $50 \%$ $\mathrm{CO}_{2}$ up to $1675 \mathrm{~K}$ at $10 \mathrm{~K} / \mathrm{min}$.

Table 1 is about 5000 times faster than its $\mathrm{CO}_{2}$ gasification at $1273 \mathrm{~K}$.

The reaction order with respect to $\mathrm{CO}_{2}$ has been derived from eq 3 .

$$
k_{0}=A_{0} P_{\mathrm{CO}_{2}}^{n}
$$

Here, $k_{0}$ is the re-estimated value obtained by fixing a common activation energy in eq 2 for the gasification of the soot sample obtained at $1475 \mathrm{~K}$ and $78.5 \% \mathrm{CO}_{2}$ (set 12 in Table 1), with 10,50 , and $90 \% \mathrm{CO}_{2}$ (values presented in Table 4). $n$ is the order of the reaction expressed as an exponent of the reaction of $\mathrm{CO}_{2}$ partial pressure $P_{\mathrm{CO}_{2}}$ (atm). Figure 10 shows the fitting of the experimental data to eq 3 for the experiments of soot 12 gasification with different $\mathrm{CO}_{2}$ concentrations, along with the linear regression results. An order with respect to $\mathrm{CO}_{2}$ of 0.98 is obtained. This order is similar to the reaction order of around 1 with respect to $\mathrm{O}_{2}$ determined previously by several authors for the oxidation of $\operatorname{soot}^{24,25}$ and higher than the apparent reaction order found in the literature for char gasification, which varies around 0.5. ${ }^{26}$

\section{CONCLUSION}

An experimental and kinetic study on the oxidation and gasification of soot samples from different temperature/ environment formation conditions has been carried out. Soot samples were prepared from the pyrolysis of ethylene at 1275 , 1375 , and $1475 \mathrm{~K}$ and for $\mathrm{CO}_{2}$ atmospheres of $0,25,50$, and $78.5 \% \mathrm{CO}_{2}$. 


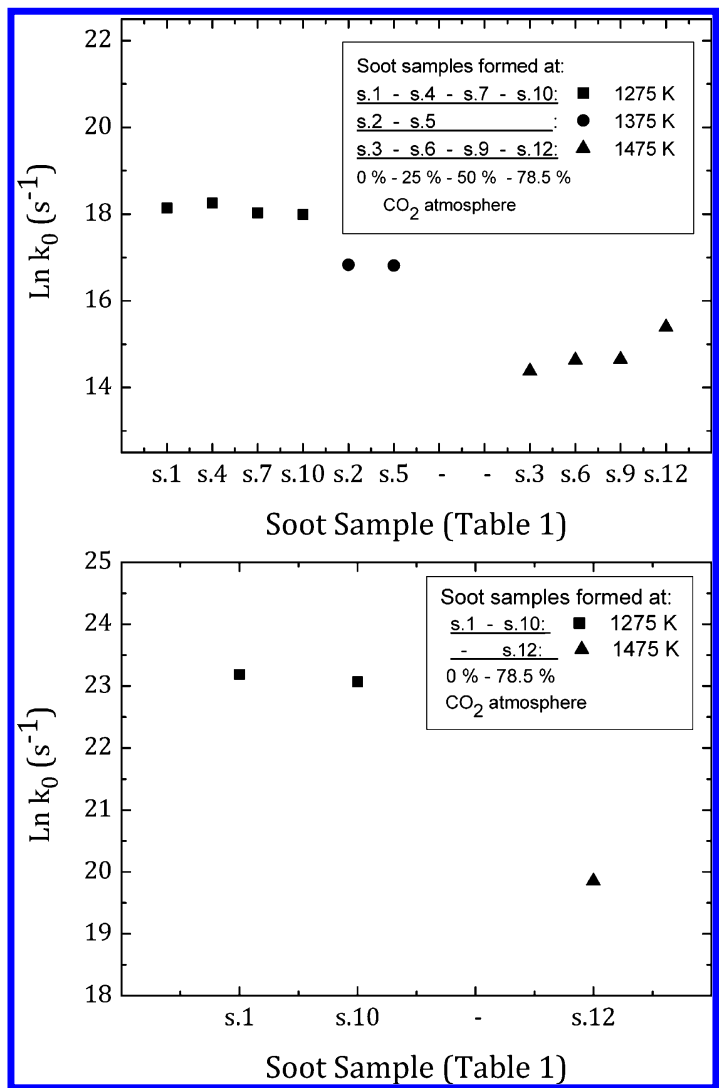

Figure 9. Estimated $k_{0}$ values for constant activation energy in VRM of both the oxidation (upper panel; $E_{\mathrm{a}}=182 \mathrm{~kJ} / \mathrm{mol}$ ) and gasification (bottom panel; $E_{\mathrm{a}}=326 \mathrm{~kJ} / \mathrm{mol}$ ) reactivities as a function of the temperature/environment history of the soot samples (Table 1).

Table 4. Kinetic Constants of Soot Gasification of Soot Sample 12 in Table 1 with 10, 50, and $90 \% \mathrm{CO}_{2}{ }^{a}$

$\begin{array}{cccc}{\left[\mathrm{CO}_{2}\right](\%)} & E_{\mathrm{a}}(\mathrm{kJ} / \mathrm{mol}) & \text { common } E_{\mathrm{a}}(\mathrm{kJ} / \mathrm{mol}) & k_{0}\left(\mathrm{~s}^{-1}\right)(\mathrm{VRM}) \\ 10 & 345 & & 8.57 \times 10^{7} \\ 50 & 339 & 326 & 4.18 \times 10^{8} \\ 90 & 347 & & 7.43 \times 10^{8}\end{array}$

${ }^{a}$ Activation energies were based on VRM and pre-exponential factors assuming a common activation energy for gasification reactivities in VRM.

The reactivity of the soot samples was determined in nonisothermal experiments using a TGA. Oxidation was carried out in $5 \% \mathrm{O}_{2}$ at a heating rate of $10 \mathrm{~K} \mathrm{~min}^{-1}$ to a maximum temperature of $1275 \mathrm{~K}$, and gasification was carried out in 10 , 50 , and $90 \% \mathrm{CO}_{2}$ at a heating rate of $10 \mathrm{~K} \mathrm{~min}^{-1}$ to a maximum temperature of $1675 \mathrm{~K}$. The experiments showed that, for both $\mathrm{O}_{2}$ and $\mathrm{CO}_{2}$, the soot sample reactivity decreased when increasing the formation temperature of the soot sample. We attribute this to a graphitization process as the soot formation temperature increases. For both oxidation and gasification, the reactivity decreased by a factor of about 27 when increasing the soot formation temperature from 1275 to $1475 \mathrm{~K}$. However, with regard to the influence of the gas environment during the formation of the soot, appreciable differences in the reactivity have been found only for the soot formed at $1475 \mathrm{~K}$ in $\mathrm{N}_{2}$ and $78.5 \% \mathrm{CO}_{2}$ when oxidized with $5 \% \mathrm{O}_{2}$. For this soot, the reactivity was observed to increase by a factor of about 2.6 compared to soot formed in $\mathrm{N}_{2}$ at the same temperature. We attribute the increased reactivity to a higher micropore surface

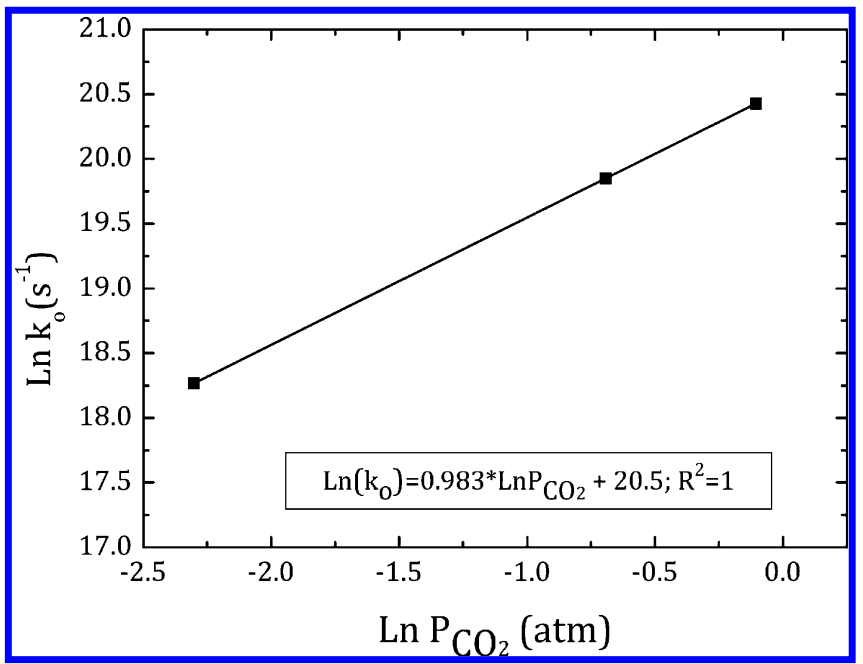

Figure 10. Determination of the reaction order with respect to $\mathrm{CO}_{2}$ according to eq 3 in the gasification of soot sample 12 in Table 1 with 10,50 , and $90 \% \mathrm{CO}_{2}$.

area, facilitated by the gasification reaction at high temperatures. For all soot samples analyzed, oxidation by $\mathrm{O}_{2}$ was initiated at much lower temperatures (about $450 \mathrm{~K}$ ) than gasification by $\mathrm{CO}_{2}$.

Intrinsic kinetics in terms of Arrhenius parameters by applying the volumetric reaction model (VRM) for oxidation and gasification of soot samples has been obtained from the reactivity profiles. The activation energy for oxidation of the different soot samples was in the range of $152-235 \mathrm{~kJ} / \mathrm{mol}$, while for gasification, it was 279-347 kJ/mol. A common activation energy of $182 \mathrm{~kJ} / \mathrm{mol}$ for oxidation and $326 \mathrm{~kJ} / \mathrm{mol}$ for gasification fitted the data fairly well. The reaction order with respect to $\mathrm{CO}_{2}$ was found to be 0.98 .

\section{AUTHOR INFORMATION}

\section{Corresponding Author}

*E-mail: uxue@unizar.es.

\section{Notes}

The authors declare no competing financial interest.

\section{ACKNOWLEDGMENTS}

The authors express their gratitude to Projects DGA-LC031/ 2009 (GA-La Caixa) and CTQ2009-12205 (MICINN), EUCOST Action CM0901 (Ref. ECOST-STSM-CM0901100111-004196), and the CHEC Research Program, for financial support. Maria Abián acknowledges Obra Social CAI through Programa Europa for the grant awarded and the University of Zaragoza and GPT Research Group for the predoctoral grant awarded (PIF-UZ-2009-TEC-04).

\section{REFERENCES}

(1) Stanmore, B. R.; Brilhac, J. F.; Gilot, P. Carbon 2001, 39, 22472268.

(2) Ruiz, M. P.; Callejas, A.; Millera, A.; Alzueta, M. U.; Bilbao, R. Int. J. Chem. React. Eng. 2007, 5, A50.

(3) Mendiara, T.; Alzueta, M. U.; Millera, A.; Bilbao, R. Energy Fuels 2008, 22, 284-290.

(4) Buhre, B. J. P.; Elliott, L. K.; Sheng, C. D.; Gupta, R. P.; Wall, T. F. Prog. Energy Combust. Sci. 2005, 31, 283-307.

(5) Toftegaard, M. B.; Brix, J.; Jensen, P. A.; Glarborg, P.; Jensen, A. D. Prog. Energy Combust. Sci. 2010, 36, 581-625. 
(6) Hurt, R. H.; Sarofim, A. F.; Longwell, J. P. Combust. Flame 1993, 95, 430-432.

(7) Ruiz, M. P.; Guzman de Villoria, R.; Millera, A.; Alzueta, M. U.; Bilbao, R. Chem. Eng. I. 2007, 127, 1-9.

(8) Borrego, A. G.; Álvarez, D. Energy Fuels 2007, 21, 3171-3179.

(9) Várhegyi, G.; Szabó, P.; Jakab, E.; Till, F. Energy Fuels 1996, 10, 1208-1214.

(10) Duan, L.; Zhao, C.; Zhou, W.; Qu, C.; Chen, X. Energy Fuels 2009, 23, 3826-3830.

(11) Li, Q.; Zhao, C.; Chen, X.; Wu, W.; Li, Y. I. Anal. Appl. Pyrolvsis 2009, 85, 521-528.

(12) Rathnam, R. K.; Elliott, L. K.; Wall, T. F.; Liu, Y.; Moghtaderi, B. Fuel Process. Technol. 2009, 90, 797-802.

(13) Ruiz, M. P.; Guzman de Villoria, R.; Millera, A.; Alzueta, M. U.; Bilbao, R. Ind. Eng. Chem. Res. 2007, 46, 7550-7560.

(14) Esarte, C.; Millera, A.; Bilbao, R; Alzueta, M. U. Fuel Process. Technol. 2009, 90, 496-503.

(15) Zolin, A.; Jensen, A. D.; Jensen, P. A.; Dam-Johansen, K. Fuel 2002, 81, 1065-1075.

(16) Rodríguez-Fernández, J.; Oliva, F.; Vázquez, R. A. Energv Fuels 2011, 25, 2039-2048.

(17) Zolin, A.; Jensen, A.; Pedersen, L. S.; Dam-Johansen, K.; Tørslev, P. Enerov Fuels 1998, 12, 268-276.

(18) Russell, N. V.; Beeley, T. J.; Man, C.-K.; Gibbins, J. R.; Williamson, J. Fuel Process. Technol. 1998, 57, 113-130.

(19) Zhang, H.; Pu, W.-X.; Ha, S.; Li, Y.; Sun, M. Fuel 2009, 88, 2303-2310.

(20) Shim, H.-S.; Hurt, R. H. Energy Fuels 2000, 14, 340-348.

(21) Rockne, K. J.; Taghon, G. L.; Kosson, D. S. Chemosphere 2000, $41,1125-1135$.

(22) Guerrero, M.; Ruiz, M. P.; Alzueta, M. U.; Bilbao, R.; Millera, A. I. Anal. Appl. Pyrolysis 2005, 74 (2005), 307-314.

(23) Dutta, S.; Wen, C. Y.; Belt, R. I. Ind. Eng. Chem. Process Des. Dev. 1977, 16 (1), 20-30.

(24) Gilot, P.; Bonnefoy, F.; Marcuccilli, F.; Prado, G. Combust. Flame 1993, 95, 87-100.

(25) Mendiara, T.; Alzueta, M. U.; Millera, A.; Bilbao, R. Enerov Fuels 2007, 21, 3208-3215.

(26) Liu, H.; Luo, C.; Toyota, M.; Uemiya, S.; Kojima, T. Fuel Process. Technol. 2006, 87, 769-774. 